\title{
Direct Evidence of Less Charge Accumulation in Highly Durable Polymer Solar Cells Using Operando ESR Spectroscopy
}

Dong Xue ${ }^{\dagger}$, Shinpei Kamiya ${ }^{\dagger}$, Masahiko Saito ${ }^{\ddagger}$, Itaru Osaka $a^{\ddagger}$, and Kazuhiro Marumoto ${ }^{\dagger \S}$

†Division of Materials Science, University of Tsukuba, Tsukuba, Ibaraki, 305-8573, Japan

${ }^{\ddagger}$ Graduate School of Engineering, Hiroshima University, Higashihiroshima, Hiroshima, 739-

8527, Japan

${ }^{\S}$ Tsukuba Research Center for Energy Materials Science (TREMS), University of Tsukuba,

Tsukuba, Ibaraki, 305-8571, Japan

*Correspondence should be addressed to marumoto@ims.tsukuba.ac.jp 


\section{ABSTRACT:}

Inverted-type polymer solar cells with poly[naphtho[1,2-c:5,6-c']bis[1,2,5]thiadiazole-5,10diyl[3,4'-bis(2-butyloctyl)[2,2'-bithiophene]-5,5'-diyl] thiazolo[5,4-d] thiazole-2,5-diyl[3',4-bis (2-butyloctyl)[2,2'-bithiophene]-5,5'-diyl]] (PTzNTz) have attracted attention because of its high power conversion efficiency and thermal stability. However, the internal deterioration mechanism hasn't yet been completely clarified. Here, we report operand electron spin resonance (ESR) spectroscopy of the highly durable PTzNTz polymer solar cells to investigate the mechanism of the device-performance deterioration at a molecular level. We identify the layer with accumulated charges in the PTzNTz cells by the analyses of light-induced components in the ESR spectra of the thin films and cells with PTzNTz. We observe the correlation between the increase in the number of spins and the decrease in the device performance. Notably, compared to the previously reported ESR studies of polymer solar cells, the PTzNTz solar cells have less charge accumulation and higher durability. This correlation holds even if another hole-transport layer of PTzNTz solar cells is utilized. The calculation with density functional theory is performed to analyze the charge-accumulation states in the cells. The present results are useful to develop further highly efficient and durable polymer solar cells.

KEYWORDS: Organic photovoltaics, Electron spin resonance spectroscopy, Charge accumulation, Durability of PTzNTz polymer solar cells, Density functional theory calculation 


\section{INTRODUCTION}

Polymer solar cells have been extensively investigated as they have characteristics such as low manufacturing cost, enabling large-area, and flexibility that are difficult to be realized with silicon-based solar cells. ${ }^{1-3}$ In recent years, the power conversion efficiency (PCE) of polymer solar cells has been remarkably improved; however, the internal deterioration mechanism hasn't yet been completely clarified. For organic semiconductors typically used in polymer solar cells, poly(3-hexylthiophene) (P3HT) and [6,6]-phenyl-C61-butyric acid methyl ester $\left(\mathrm{PC}_{61} \mathrm{BM}\right)$ have been used as a p- and n-type semiconductor, respectively, where the PCEs of $4-6 \%$ have been reported for the solar cells using these blend-film layers as active layers. ${ }^{4,5}$ For these typical polymer solar cells, a clear correlation between accumulated charges and the device-performance deterioration has been reported. ${ }^{6}$ In addition, studies of highly efficient polymer solar cell with poly[(4,8-bis-(2-ethylhexyloxy)-benzo(1,2-b:4,5-b)dithiophene)-2,6diyl-alt-(4-(2-ethylhexyl)-3-fluorothieno[3,4-b]thiophene-)-2-carboxylate-2-6-diyl)] (PTB7) or poly[4,8-bis(5-(2-ethylhexyl)thiophen-2-yl)benzo[1,2-b;4,5-b]dithiophene-2,6-diyl-alt(4-(2-ethylhexyl)-3-fluorothieno[3,4-b]thiophene-)-2-carboxylate-2-6-diyl)] (PTB7-Th) have also reported such performance deterioration. ${ }^{7,8}$ These reports have indicated that the charge accumulation contributes to the decrease in the device performance. In contrast to the above solar cells, inverted-type polymer solar cells with semiconducting polymers based on PTzNTz, (Figure 1a) have attracted attention because they have both high PCE and thermal stability. ${ }^{9}$ 
PTzNTz has a narrow band gap (1.57-1.58 eV), and the maximum PCE of $9.0 \%$ has been reported for inverted-type polymer solar cells with PTzNTz and [6,6]-phenyl C71-butyric acid methyl ester ( $\left.\mathrm{PC}_{71} \mathrm{BM}\right) .{ }^{9}$ These solar cells have excellent thermal stability that the PCE hasn't almost changed even after the storage at $85^{\circ} \mathrm{C}$ for $500 \mathrm{~h}$ in a nitrogen-filled glove box $\left(\mathrm{O}_{2}<0.2\right.$ ppm, $\mathrm{H}_{2} \mathrm{O}<0.5 \mathrm{ppm}$ ) under dark conditions under open-circuit conditions, and thus are expected as high PCE and stability polymer solar cells. ${ }^{9}$

Oxygen and moisture have been reported as external degradation factors for polymer solar cells. ${ }^{10-12}$ Sealing the solar cells can suppress the extrinsic irreversible degradations. ${ }^{13-19}$ However, the sealing of the cells cannot prevent the internal deterioration factors such as charge accumulation. Electron spin resonance (ESR) spectroscopy is a useful method that can investigate accumulated charge states in polymer solar cells directly at a molecular level. ${ }^{20-23}$ Several groups have studied organic solar-cell materials using the ESR technique. ${ }^{24-29}$ It is very interesting to investigate accumulated charge states in PTzNTz polymer solar cells which have superior durability compared to P3HT, PTB7 or PTB7-Th polymer solar cells. However, the internal deterioration factors for PTzNTz solar cells have not yet been studied.

In this study, we have applied operand light-induced ESR spectroscopy to PTzNTz polymer solar cells, and have investigated accumulated-charge states during device operation, 
and have clarified the internal deterioration mechanism at a molecular level. We have observed monotonic increases in the ESR intensity of the cells under simulated solar irradiation. The fitting analysis of the ESR spectra shows that two components exist in the light-induced ESR spectra which are identified as a signal due to holes in PTzNTz and a signal due to electrons on PC71BM, which contributes the device-performance deterioration. This deep understanding of the internal deterioration mechanism would be important for optimizing the device structures and for improving the PCE and durability of polymer solar cells.

\section{MATERIALS AND DEVICE FABRICATION}

In the present work, the polymer solar cells were fabricated with PTzNTz-BOBO (Figure 1a), which is PTzNTz with two 2-butyloctyl group, and $\mathrm{PC}_{71} \mathrm{BM}$ (Solenne BV, purity $>99 \%)$. The structure of polymer solar cell (ITO/ZnO/PTzNTz:PC $\left.71 \mathrm{BM} / \mathrm{MoO}_{x} / \mathrm{Ag}\right)$ is shown

in Figure 1b. ZnO (electron transport layer, $40 \mathrm{~nm}$ ) and PTzNTz:PC71BM (active layer, 100$150 \mathrm{~nm}$ ) were deposited with a spin-coating method on an indium tin oxide (ITO) substrate used for a transparent electrode. Then hole transport layer (HTL) of $\mathrm{MoO}_{x}(7.5 \mathrm{~nm})$ or $\mathrm{WO}_{x}(15$ $\mathrm{nm}$ ) and $\mathrm{Ag}$ (hole collecting electrode, $100 \mathrm{~nm}$ ) were deposited by a vacuum-deposition method to complete the solar cells. We sealed the cell in an ESR sample tube after wiring in a nitrogenfilled globe box. The ESR spectra and device performance were measured simultaneously 
under dark or simulated solar irradiation conditions using AM1.5G, $100 \mathrm{~mW} / \mathrm{cm}^{2}$ solar simulator (OTENTOSUN-150LX). Moreover, to identify the signals obtained from the solar cells, thin-film samples of PTzNTz:PC ${ }_{71} \mathrm{BM}$ and PTzNTz:PC ${ }_{61} \mathrm{BM}$ were fabricated by the spincoating method, and were studied by light-induced ESR spectroscopy under the same conditions used for the cells.

\section{RESULTS AND DISCUSSION}

\subsection{Operando ESR Measurements.}

ESR is a magnetic resonance phenomenon occurring for unpaired electrons, which is a non-destructive and highly sensitive method that can evaluate materials at the molecular level by observing the microwave absorption at the resonance. We used the continuous-wave ESR method in the experiments which performs a lock-in detection with an external magnetic field (H) modulation of $100 \mathrm{kHz}$. Therefore, photogenerated charges with a lifetime $(<10 \mu \mathrm{s})$ contributing to standard device operation can't be observed, and it is possible to observe only long-lived (or accumulated) photogenerated charges with an unpaired spin with a long lifetime $(>10 \mu \mathrm{s})$ in solar cells. ${ }^{6,7,8}$

We simultaneously measured the ESR signals of our sample and a same standard Mn2+ marker sample in the same ESR cavity in all ESR measurements in order to compare these $\mathrm{g}$ factors directly. The calibration of the $\mathrm{g}$ factor was performed by using a software program of 
the ESR system considering high second-order correction of the effective resonance field. Its correctness was also confirmed by using 2,2-diphenyl-1-picrylhydrazyl (DPPH) as another standard sample. The present ESR system significantly reduces experimental errors because the fluctuation of experimental conditions such as microwave power etc. can be calibrated by using the signal of the marker sample.

By using operand ESR measurements, it is possible to investigate accumulated charge states in the cells directly during device operation. To examine the correlations between the device performance and ESR spectra of the cells, we simultaneously measured the device performance and ESR spectra under simulated solar irradiation at room temperature. The lightinduced ESR spectra are differential spectra between ESR spectra obtained from under dark and simulated solar irradiation conditions. We can study the effect of the irradiation for the cells. In our study, the substrate plane was parallel to the external magnetic field $H$. All measured light-induced spectra were averaged under $1 \mathrm{~h}$ irradiation.

\subsection{Operando ESR Spectra of PTzNTz Solar Cells with $\mathrm{MoO}_{x} \mathrm{HTL}$.}

The light-induced ESR spectra of the fabricated cells are shown in Figure 2. As the duration of the light irradiation increased, the intensity of the light-induced ESR signals increased under short- (Figure 2a) and open-circuit conditions (Figure 2b), respectively, which 
indicate that charges with spins are accumulated. The ESR parameters under short-circuit conditions are $g$ factor $g=2.0024( \pm 0.0002)$, and peak-to-peak ESR linewidth $\Delta H_{\mathrm{pp}}=$ $0.27( \pm 0.02) \mathrm{mT}$; the ESR parameters under open-circuit conditions are $g=2.0024( \pm 0.0002)$, and $\Delta H_{\mathrm{pp}}=0.26( \pm 0.02) \mathrm{mT}$. The $g$ factor can be evaluated from the resonant magnetic field. ${ }^{7}$ All the ESR parameters have been calibrated using a standard sample $\mathrm{Mn}^{2+}$ marker. Since we didn't find any anisotropy of ESR signals of the PTzNTz cells by changing the $H$ direction with respective to the substrate plane in the ESR measurements, the location of accumulated charges has been confirmed as amorphous.

\subsection{Fitting Analyses of Light-Induced ESR Spectra.}

To find out components in the light-induced ESR spectra, a least-squares fitting analyses were performed. After having tried various functions using Igor Pro 6.36J and EasySpin 6.0.0dev.17, we have found that the best result can be described using the sum of separate Lorentzian and Gaussian functions. The results of the fitting analyses for the light-induced ESR spectra of the device obtained after $20 \mathrm{~h}$ light irradiation are shown in Figure 3. The axis of ordinate is plotted with a unit of $I_{\mathrm{Mn}}$, which is a peak-to-peak ESR intensity of the standard sample $\mathrm{Mn}^{2+}$ marker. We have obtained similar component signals by the fitting analyses under short(Figure 3a) and open-circuit condition (Figure 3b), respectively. The results of the fitting analyses under short-circuit conditions are evaluated as follows: Comp. 1 has a Gauss-type 
lineshape and the ESR parameters $g_{1}=2.0022( \pm 0.0002), \Delta H_{\mathrm{pp} 1}=0.20( \pm 0.02) \mathrm{mT}$; Comp. 2 has a Lorentz-type lineshape and the ESR parameters $g_{2}=2.0030( \pm 0.0002), \Delta H_{\mathrm{pp} 2}=0.16( \pm 0.02)$ mT. Also, similar components have been identified from the results of the fitting analyses under open-circuit conditions, where we have obtained that the $g$ factor of the Gauss-type Comp. 1 and the Lorentz-type Comp. 2 are $g_{1}=2.0022( \pm 0.0002)$ and $g_{2}=2.0031( \pm 0.0002)$, respectively, and the $\Delta H_{\mathrm{pp}}$ of Comp. 1 and Comp. 2 are $\Delta H_{\mathrm{pp} 1}=0.21( \pm 0.02) \mathrm{mT}$ and $\Delta H_{\mathrm{pp} 2}=$ $0.17( \pm 0.02) \mathrm{mT}$, respectively.

\subsection{Origins of Charge Accumulation in Solar Cells.}

Investigating the origin of these charge-accumulation states is a very interesting issue to clarify the internal deterioration mechanism of the cells. For this purpose, thin-film samples were fabricated and studied to identify the origin of these ESR signals. Thin-film samples of active layers of $\mathrm{PTzNTz:PC}{ }_{71} \mathrm{BM}$ and $\mathrm{PTzNTz:PC}{ }_{61} \mathrm{BM}$ were fabricated by the spin-coating method on the quartz substrates under the same condition used for cells, and the ESR spectra were observed using ESR spectroscopy. The ESR spectrum of the sample PTzNTz:PC ${ }_{71} \mathrm{BM}$ is shown in the red line in Figure 4a. The obtained $g=2.0024( \pm 0.0001)$ and $\Delta H_{\mathrm{pp}}=0.24( \pm 0.01)$ $\mathrm{mT}$ accord with the result of the cells (see Table 1). This accordance shows that charges have accumulated in PTzNTz:PC71 BM (active layer) in the cells by light irradiation. 
The green line in Figure 4a shows the ESR spectrum of the PTzNTz:PC 61 BM sample. The ESR parameters are evaluated as $g=2.0022( \pm 0.0001)$ and $\Delta H_{\mathrm{pp}}=0.18( \pm 0.01) \mathrm{mT}$. In the case using $\mathrm{PC}_{61} \mathrm{BM}$, the obtained signal can be identified as a hole signal of PTzNTz because the spinlattice relaxation time of $\mathrm{PC}_{61} \mathrm{BM}$ is so short that the signal cannot be observed at room temperature (see Figure 3a and Figure S1(Supporting Information)). ${ }^{6,7}$ The spin-lattice relaxation time is the time of transfer of the absorbed microwave energy to lattice vibration. This signal's ESR parameters accord with those of the Comp. 1 from the fitting analyses of the cells. In the previous study, $\mathrm{PC}_{71} \mathrm{BM}$ radical anions have been reported to exhibit the principal values for the fully resolved $g$ tensor from 2.0021 to 2.0060 , and thus the signal of fullerene overlapped with that of polymers in these studies. ${ }^{7,8,30-32}$ In the case of the PTzNTz:PC71BM sample, the $\mathrm{PC}_{71} \mathrm{BM}$ signal can be observed at room temperature and has overlapped with the PTzNTz signal. Thus, we can obtain the $\mathrm{PC}_{71} \mathrm{BM}$ signal by evaluating the difference between the PTzNTz:PC 71 BM and PTzNTz:PC ${ }_{61} \mathrm{BM}$ signals. The differential signal is shown by the orange dotted line in Figure 4a. The ESR parameter of this differential signal accord with those of the Comp. 2 from the fitting analyses of the cells (see Figure 3, Table 2). In order to enhance the accuracy of the fitting results, the ESR spectrum of the PTzNTz:PC $71 \mathrm{BM}$ sample has been analyzed with a fitting calculation, which shows that the fitting results are able to reproduce the signal of $\mathrm{PC}_{71} \mathrm{BM}$ anions well (see Figure 4b, Table 2). We have observed the same difference ESR signal of $\mathrm{PC}_{71} \mathrm{BM}$ radical anions from the ESR spectra of PTNTz:PC71BM and 
PTzNTz:PC $61 \mathrm{BM}$ films not only under the $H$ parallel to the substrate but also under the $H$ perpendicular to the substrate. This result indicates that the molecular orientation of the polymer is not significantly affected by different fullerenes in the blend films.

As demonstrated above, the accumulated charges in the PTzNTz:PC $71 \mathrm{BM}$ layer are the origin for the signal increase in the cells irradiated by solar simulator under short- or opencircuit conditions. According to the results of the fitting analyses, the Comp. 1 is identified as the hole (cation) signal of PTzNTz, and the Comp. 2 is identified as the electron (anion) signal of $\mathrm{PC}_{71} \mathrm{BM}$ in the cells and thin-film samples. In other words, it is proved that holes in PTzNTz and electrons on $\mathrm{PC}_{71} \mathrm{BM}$ have been accumulated by simulated solar irradiation. It has been reported that charges are accumulated at the interface between PEDOT:PSS and P3HT, PTB7 or PTB7-Th. ${ }^{6,7,8}$ However, such accumulation hasn't been observed in these highly durable cells.

3.5. Correlation between ESR Intensity and Device Performance.

It is interesting to find out the correlations between the number of accumulated charges and the cell's performance. Thus, we have compared the change of the number of accumulated charges $\left(N_{\text {spin }}\right)$ and the performance of the cells. The ESR signals were double integrated and compared with the signal of the standard sample $\mathrm{Mn}^{2+}$ marker to evaluate the $N_{\text {spin }}$ 
corresponding to the charge's accumulation. We measured the transient response of this $N_{\text {spin }}$ and the device characteristics simultaneously under simulated solar irradiation. Figure 5a shows the time dependence of the $N_{\text {spin }}$ obtained from the light-induced ESR spectra and relative short-circuit current density $\left(J_{\mathrm{sc}}(t) / J_{\mathrm{sc}}(0)\right)$ of the cells. The time dependence of the $N_{\text {spin }}$ and relative open-circuit voltage $\left(V_{\mathrm{oc}}(t) / V_{\mathrm{oc}}(0)\right)$ is shown in Figure 5b. Even for the cells with

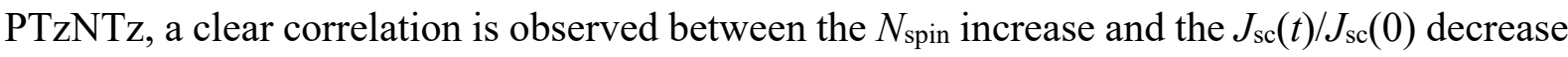
under simulated solar irradiation, as reported by the ESR studies of the solar cells with P3HT, PTB7 or PTB7-Th. ${ }^{6,78}$ Moreover, a correlation is also observed between the $N_{\text {spin }}$ increase and the $V_{\mathrm{oc}}(t) / V_{\mathrm{oc}}(0)$ decrease. In the cases of the cells with P3HT, PTB7 or PTB7-Th, the large $V_{\mathrm{oc}}(t) / V_{\mathrm{oc}}(0)$ decrease has been observed. ${ }^{6,7,8}$ In contrast, only a slight $V_{\mathrm{oc}}(t) / V_{\mathrm{oc}}(0)$ decrease has been observed for the cells with PTzNTz. Green squares and orange triangles in Figure 5a,b show the time dependence of the $N_{\text {spin }}$ for the Comp. 1 and Comp. 2 under simulated solar irradiation, respectively. The sum of these two components correspond to the total $N_{\text {spin. }}$. The $N_{\text {spin }}$ of the Comp. 1 and Comp. 2 has been obtained by the deconvolution of the ESR spectra as shown in Figure 3. As the duration of simulated solar irradiation increases, both the $N_{\text {spin }}$ of the Comp. 1 and Comp. 2 increase. Moreover, it is found that the ratio of the cation $N_{\text {spin }}$ (Comp. 1) to the anion $N_{\text {spin }}$ (Comp. 2) is approximately $1: 1$. This result means that the number of accumulated holes in PTzNTz and that of accumulated electrons on $\mathrm{PC}_{71} \mathrm{BM}$ are almost the same with each other in the active layer of the cells. In the previous light-induced ESR studies, 
the light-induced ESR signals of thin-film samples have been observed at low temperature. ${ }^{33-35}$ In these cases, the signal intensity is saturated by spin-lattice relaxation time, and the evaluated $N_{\text {spin }}$ of holes in polymers and electrons on fullerenes may not be equal each other. We have measured the PTzNTz:PCBM solar cells at room temperature so the signals are not saturated and the $N_{\text {spin }}$ of holes and electrons photoinitiated in the PTzNTz:PC71 BM composite are approximately equal.

\subsection{Deterioration Mechanism of PTzNTz Solar Cells.}

We now turn to a discussion of the mechanism which has deteriorated the device performance. When charges are accumulated in cells, the short-circuit current density is described as a function of $N_{\text {spin }}$ as follows: ${ }^{36,37}$

$$
J_{\mathrm{sc}}\left(N_{\mathrm{spin}}\right)=N e \mu E=n e \frac{\mu_{\mathrm{SC}} \mu_{\mathrm{CA}}}{\mu_{\mathrm{CA}}+\left(\mu_{\mathrm{SC}} / c\right) N_{\mathrm{spin}}} E .
$$

Here, $e$ is elementary charge, $N$ is charge density, $\mu$ is the mobility of Matthiessen's rule, $E$ is internal electric field, $\mu_{\mathrm{SC}}$ is the mobility without charge accumulation, $\mu_{\mathrm{CA}}$ is the mobility with charge accumulation, and $c$ is a proportional constant. From Equation (1), we obtain $J(0)=$ $N e \mu_{\mathrm{SC}} E$, which gives $J_{\mathrm{sc}}\left(N_{\mathrm{spin}}\right) / J_{\mathrm{sc}}(0)$ as follows:

$$
\frac{J_{\mathrm{sc}}\left(N_{\mathrm{spin}}\right)}{J_{\mathrm{sc}}(0)}=\frac{\mu_{\mathrm{CA}}}{\mu_{\mathrm{CA}}+\left(\mu_{\mathrm{SC}} / c\right) N_{\mathrm{spin}}}=\frac{1}{1+\left(\frac{\mu_{\mathrm{SC}}}{C \cdot \mu_{\mathrm{CA}}}\right) N_{\mathrm{spin}}} .
$$


From Equation (2), we can know that the $J_{\mathrm{sc}}$ decreases as the $N_{\text {spin }}$ increases because the collision time decreases due to the charge-carrier scattering by accumulated charges. The dependence of the $J_{\mathrm{sc}}\left(N_{\mathrm{spin}}\right) / J_{\mathrm{sc}}(0)$ on the $N_{\text {spin }}$ is shown in Figure 6a. The red circles show the experimentally

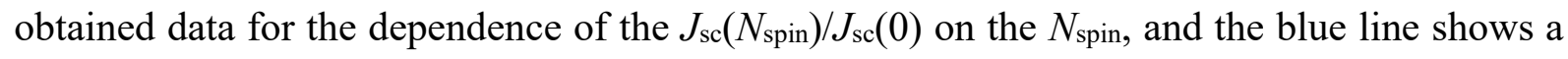
least-squares fitting result with Equation (2). We have found that the fitting result with Equation (2) is roughly in accord with the experimental values obtained under short-circuit conditions.

Next, we discuss the reason why the $V_{\text {oc }}$ has decreased under simulated solar irradiation.

The relation between $V_{\mathrm{oc}}$ and $J_{\mathrm{sc}}$ has been reported using an equivalent circuit as follows: ${ }^{38}$

$$
V_{\mathrm{oc}} \approx \frac{n k_{\mathrm{B}} T}{e} \ln \left(\frac{J_{\mathrm{sc}}}{J_{0}}\right) \text {. }
$$

Here, $k_{\mathrm{B}}$ is the Boltzmann constant, $T$ is the temperature, $J_{0}$ is the reverse saturation current density, and $n$ is ideality factor. From Equations (2) and (3), we may describe the relative opencircuit voltage $\left(V_{\mathrm{oc}}\left(N_{\mathrm{spin}}\right) / V_{\mathrm{oc}}(0)\right)$ as a function of $N_{\text {spin }}$ as follows:

$$
\frac{V_{\mathrm{oc}}\left(N_{\mathrm{spin}}\right)}{V_{\mathrm{oc}}(0)}=1+\frac{1}{\ln \left(\frac{N e \mu_{\mathrm{SC}} E}{J_{0}}\right)} \ln \left[\frac{1}{1+\left(\frac{\mu_{\mathrm{SC}}}{C^{\cdot} \mu_{\mathrm{CA}}}\right) N_{\mathrm{spin}}}\right]
$$

Here, the $\ln \left(\frac{N e \mu_{\mathrm{SC}} E}{J_{0}}\right)$ and $\frac{\mu_{\mathrm{SC}}}{C \cdot \mu_{\mathrm{CA}}}$ are constant. The dependence of the $V_{\mathrm{oc}}\left(N_{\mathrm{spin}}\right) / V_{\mathrm{oc}}(0)$ on the $N_{\text {spin }}$ is shown in Figure $6 \mathrm{~b}$. We have found that the fitting result with Equation (4) is in accord with the experimental values obtained under open-circuit conditions. From the above results, 
it is thought that the $J_{\text {sc }}$ decrease causes the slight $V_{\text {oc }}$ decrease. For the cells with P3HT, PTB7 or PTB7-Th, it has been reported that an electric dipole layer is formed by the charge accumulation at the interface between p-type polymers and PEDOT:PSS, causing a vacuumlevel shift and contributing to the decrease in the open-circuit voltages. ${ }^{6,7,8,36}$ In contrast, the accumulated charges in the present cells with PTzNTz exist in the active layer and no vacuumlevel shift at the interface between PTzNTz and $\mathrm{MoO}_{x}$ or $\mathrm{ZnO}$ has occurred, which results in that the open-circuit voltage shows only a slight decrease under light irradiation conditions. Also, in both short- and open-circuit conditions, we have found that the present more durable polymer solar cells with PTzNTz have less charge accumulation compared to that in the cells with P3HT, PTB7 or PTB7-Th under simulated solar irradiation. ${ }^{6,7,8}$

\subsection{Effect of HTL on Charge Accumulation.}

As discussed above, considering the previously reported results of the polymer solar cells with P3HT, PTB7 or PTB7-Th, we have found the charge accumulation seems to be inversely proportional to the durability of the cells. According to the previous research, if we change the $\mathrm{MoO}_{x}$ HTL to a $\mathrm{WO}_{x}$ HTL, the stability of the PTzNTz solar cells will be further improved. ${ }^{9}$ Thus, we fabricated cells with a $\mathrm{WO}_{x}$ HTL with same-thickness active layer used for the cells with the $\mathrm{MoO}_{x} \mathrm{HTL}$ and studied them using operando ESR spectroscopy at RT. In this case, we can compare the ESR results of the different cells with the different HILs. Figure 7a shows 
the light-induced ESR spectra of the cells with a $\mathrm{WO}_{x} \mathrm{HTL}$ (red line) or $\mathrm{MoO}_{x} \mathrm{HTL}$ (blue line) after $20 \mathrm{~h}$ simulated solar irradiation. Compared with the ESR spectrum of the cell with the $\mathrm{MoO}_{x} \mathrm{HTL}$, we have found that the ESR intensity of the cell with the $\mathrm{WO}_{x} \mathrm{HTL}$ is smaller than that of the cell with the $\mathrm{MoO}_{x} \mathrm{HTL}$, where cell with the $\mathrm{WO}_{x}$ HTL have been reported more durable than the cell with the $\mathrm{MoO}_{x} \mathrm{HTL}^{9}$. We also measured the transient response of the $N_{\text {spin }}$ and the characteristics of the cells with the $\mathrm{WO}_{x} \mathrm{HTL}$ simultaneously under simulated solar irradiation (see Figure $7 \mathrm{~b}$ ). We have observed the same correlation between the $N_{\text {spin }}$ increase and the $J_{\mathrm{sc}}(t) / J_{\mathrm{sc}}(0)$ decrease. It's worth noting that the more highly durable cells with the $\mathrm{WO}_{x}$ HTL have less $N_{\text {spin }}$ increase and less $J_{\text {sc }}$ decrease than those of the cells with the MoO $\mathrm{HTL}$ The reason for the less charge accumulation in the cells with the $\mathrm{WO}_{x} \mathrm{HTL}$ may be ascribed to the difference of energy levels between two HTLs. ${ }^{39}$ This result further illustrates that charge accumulation is related to the durability of the solar cells.

\subsection{DFT Analysis of PTzNTz Cation States.}

To get more accurate identification of the Comp. 1, we have performed density functional theory (DFT) calculation using Gaussian $09 \mathrm{~W} .{ }^{40}$ In general, chain-end treatments for synthesized polymers are performed. However, the treatments are usually not perfect and the bromines are known to remain at the chain ends of polymers. ${ }^{41-43}$ In this study, we calculated the model molecules of PTzNTz without residual bromine (monomer TzNTz-H, 
dimer 2TzNTz-H, and trimer 3TzNTz-H) and PTzNTz with residual bromine (monomer TzNTz-Br, dimer 2TzNTz-Br, and trimer 3TzNTz-Br) with UB3LYP function and 6-31G(d,p) basis set. The model-molecule structures were optimized in the DFT calculation. Figure 8 shows the chemical structures of the PTzNTz model trimers and the distribution of the spin density for the cationic states. The chemical structures of the model dimer and monomer are shown in Figure S2 (Supporting Information) and Figure S3 (Supporting Information), respectively. The calculated results for all model molecules are summarized in Table 3. Since we have observed no anisotropy of the ESR spectra for PTzNTz, the charge-accumulation states are found to be amorphous. Thus, the averaged value ( $\left.g_{\text {ave }}\right)$ should be used, which can be calculated with the principal values of the $g$ tensors $g_{x}, g_{y}$, and $g_{z}$ :

$$
g_{\mathrm{ave}}=\sqrt{\frac{g_{x}{ }^{2}+g_{y}{ }^{2}+g_{z}{ }^{2}}{3}} .
$$

Since the spin density doesn't largely spread on bromine as shown in Figure 7, we have got roughly the same results for the $g_{\text {ave }}$ of the PTzNTz model molecules without or with bromine as shown in Table 3. However, if we carefully look at the DFT calculation results, the calculated $g$ values of $2 \mathrm{TzNTz}-\mathrm{Br}(g=2.00230)$ and $3 \mathrm{TzNTz}-\mathrm{Br}(g=2.00218)$ are closer to the experimentally obtained $g$ values $(g=2.0022( \pm 0.0002))($ Comp. 1$)$ than those of 2TzNTz-H $(g$ $=2.00197)$ and $3 \mathrm{TzNTz}-\mathrm{H}(g=2.00201)$. If the length of the model molecule increases, the calculated $g$ values are expected to the described experiment $g$ value. Thus, the above fitting 
analysis for the ESR spectra are supported by these DFT results, and we suggest that accumulated holes may exist near the chain ends of PTzNTz with residual bromine. . $^{7,222,44}$

\subsection{ESR Measurement at High Temperature.}

Finally, we comment on the effect of thermal treatment on the ESR characteristics since the PTzNTz cells show the excellent thermal stability at $85^{\circ} \mathrm{C}$ under dark conditions under open-circuit conditions as mentioned in Introduction. ${ }^{9}$ We have measured the ESR spectra of the PTzNTz cell after thermal treatment at $85^{\circ} \mathrm{C}$ under a nitrogen-gas condition. As the result, we have found almost no change in the ESR spectra after the thermal treatment, which may support the above excellent thermal stability. Further detail investigation into the effect of thermal treatment on the ESR characteristics using other polymer solar cells would be an interesting issue to obtain more information about the degradation mechanism of polymer solar cell, which is now in progress and will be reported in another paper.

\section{CONCLUSION}

We have studied the PTzNTz polymer solar cells by operand ESR spectroscopy under simulated solar irradiation. As the duration of the light irradiation increases, the ESR intensity of the cells increases monotonically. Moreover, light-induced two components have been found from the ESR fitting analyses, where the Comp. 1 and Comp. 2 is identified as the hole 
signal of PTzNTz and the electron signal of $\mathrm{PC}_{71} \mathrm{BM}$, respectively. A clear correlation has been observed between the $J_{\mathrm{sc}}(t) / J_{\mathrm{sc}}(0)$ decrease and the $N_{\text {spin }}$ increase, which have indicated that the collision time of charge carriers decreases due to the charge scattering by accumulated charges. In addition, a correlation between the $V_{\mathrm{oc}}(t) / V_{\mathrm{oc}}(0)$ decrease and the $N_{\text {spin }}$ increase has been also observed, which indicates that the $J_{\text {sc }}$ decrease causes the slight $V_{\text {oc }}$ decrease. Compared with the polymer solar cells with $\mathrm{P} 3 \mathrm{HT}$, PTB7 or PTB7-Th, the present $V_{\text {oc }}$ just slightly decreased, which is probably ascribed to the fact charges accumulated only at the active layer, not at the interface of the cells. The present experimental results demonstrate that the number of accumulated charges is less than that of the solar cells with P3HT, PTB7 or PTB7-Th. From this fact, it is suggested that the number of accumulated charges correlates with the durability of the cells. Thus, further decrease in the number of accumulated charges under device operation and prevention of electric dipole layers formed at the interfaces would be necessary for developing solar cells with higher durability.

\section{EXPERIMENTAL SECTION}

Fabrication of Device and Thin-Film Sample. A quartz substrate $(20 \mathrm{~mm} \times 3 \mathrm{~mm})$ with an ITO pattern $(15 \mathrm{~mm} \times 2 \mathrm{~mm})$ was cleaned with acetone and 2-propanol in ultrasonic treatment. $\mathrm{ZnO}$ precursor solution was prepared from $\left(\mathrm{CH}_{3} \mathrm{COO}\right)_{2} \mathrm{Zn} \cdot 2 \mathrm{H}_{2} \mathrm{O}(0.11 \mathrm{~g})$ and 2Aminoethanol (34 $\mu \mathrm{L})$ in $1 \mathrm{~mL}$ of 2-Methoxyethanol. $\mathrm{ZnO}$ layer was deposited by a spin- 
coating method (5000 rpm, $30 \mathrm{sec}$ ) on the ITO substrate (annealing treatment conditions in air: $\left.200{ }^{\circ} \mathrm{C}, 30 \mathrm{~min}\right) . \quad \mathrm{PTzNTz}$ and $\mathrm{PC}_{71} \mathrm{BM}$ (Frontier Carbon nanom spectra E110) $(1: 1.5 \mathrm{w} / \mathrm{w})$ dissolved in chlorobenzene (CB) solvent was mixed at $100{ }^{\circ} \mathrm{C}$ for 30 min with a vibrational method. Then, 2vol\% 1,8-diiodooctane (DIO) was added in the mixed solution. An active layer was fabricated by the spin-coating method $(600 \mathrm{rpm}, 20 \mathrm{sec})$ on the quartz/ITO/ZnO substrate in a nitrogen-filled glove box $\left(\mathrm{O}_{2}<0.2 \mathrm{ppm}, \mathrm{H}_{2} \mathrm{O}<0.5 \mathrm{ppm}\right)$. The $\mathrm{MoO}_{x}$ or $\mathrm{WO}_{x}$ and Ag layers were fabricated by a vacuum-deposition method below $4.0 \times 10^{-5} \mathrm{~Pa}$. The fabricated device was sealed in an ESR sample tube after wiring in the glove box. The active area is 10 $\mathrm{mm} \times 2 \mathrm{~mm}$. Thin-film samples of quartz/PTzNTz:PC ${ }_{11} \mathrm{BM}(1: 1.5 \mathrm{w} / \mathrm{w})(2 \mathrm{vol} \% \mathrm{DIO})$ and quartz/PTzNTz:PC ${ }_{11} \mathrm{BM}(1: 1.5 \mathrm{w} / \mathrm{w})(2 \mathrm{vol} \% \mathrm{DIO})$ were fabricated with the same spin-coating method $(600 \mathrm{rpm}, 20 \mathrm{sec})$. After spin-coating, the samples were sealed in an ESR sample tube in the glove box.

Device Characterization. The fabricated solar cells showed the following device parameters: $J_{\mathrm{sc}}=16.6 \mathrm{~mA} \mathrm{~cm}{ }^{-2}, V_{\mathrm{oc}}=0.84 \mathrm{~V}, \mathrm{FF}=0.63$, and $\mathrm{PCE}=8.8 \%$ (see Figure $\mathrm{S} 4$ (Supporting Information)). ESR measurements were performed with an X-band spectrometer (JEOL RESONANCE, JES-FA200) at a microwave power of $1.0 \mathrm{~mW}$ that was measured at the center of the resonator. We measured the cells at the center of the cavity where the direction of the magnetic field of the standing microwave is parallel to the substrate plane of the cells. The electrodes with a thickness of $100 \mathrm{~nm}$ on the solar cell reduce the $\mathrm{Q}$ value of the cavity 
resonator by a factor of about $25 \%$ because the dielectric loss due to electrodes occurs in the cavity resonator. However, we simultaneously measured the ESR signals of our sample and the same standard $\mathrm{Mn}^{2+}$ marker sample in the same ESR cavity. Thus, the influence can be calibrated by considering the signal intensity of $\mathrm{Mn}^{2+}$ marker sample and do not affect the calibration of the sensitivity determined with the $\mathrm{Mn}^{2+}$ reference signal. We simultaneously measured microwave frequency and the ESR signal of a standard $\mathrm{Mn}^{2+}$ marker sample during the ESR measurements of our samples, which enables us that all ESR spectra have been corrected to the same microwave frequency. Other details are described in the references. ${ }^{6,7,8}$ 
(a)

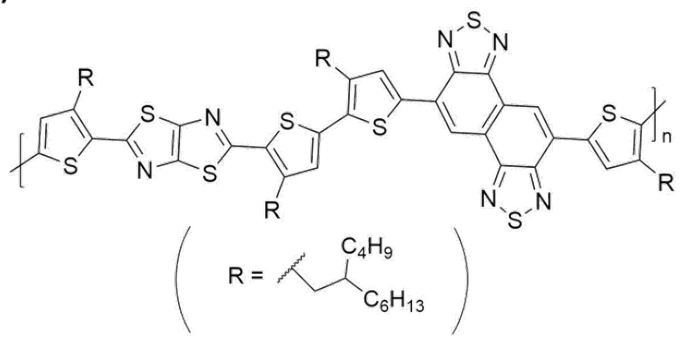

(b)

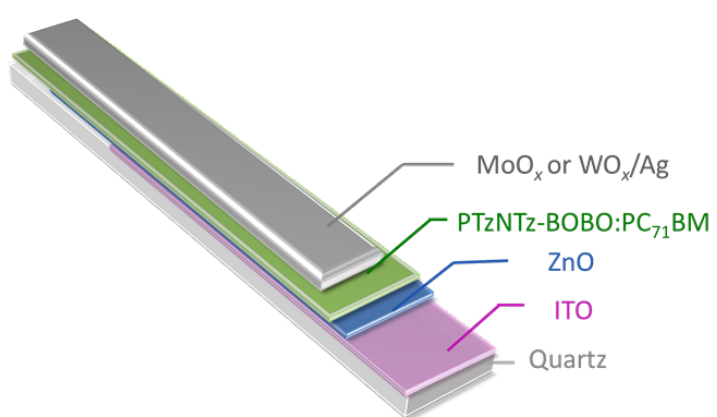

Figure 1. (a) Chemical structure of PTzNTz-BOBO. (b) Schematic of PTzNTz solar cell with $\mathrm{MoO}_{x}$ or $\mathrm{WO}_{x} \mathrm{HTL}$ used for ESR study.

(a)

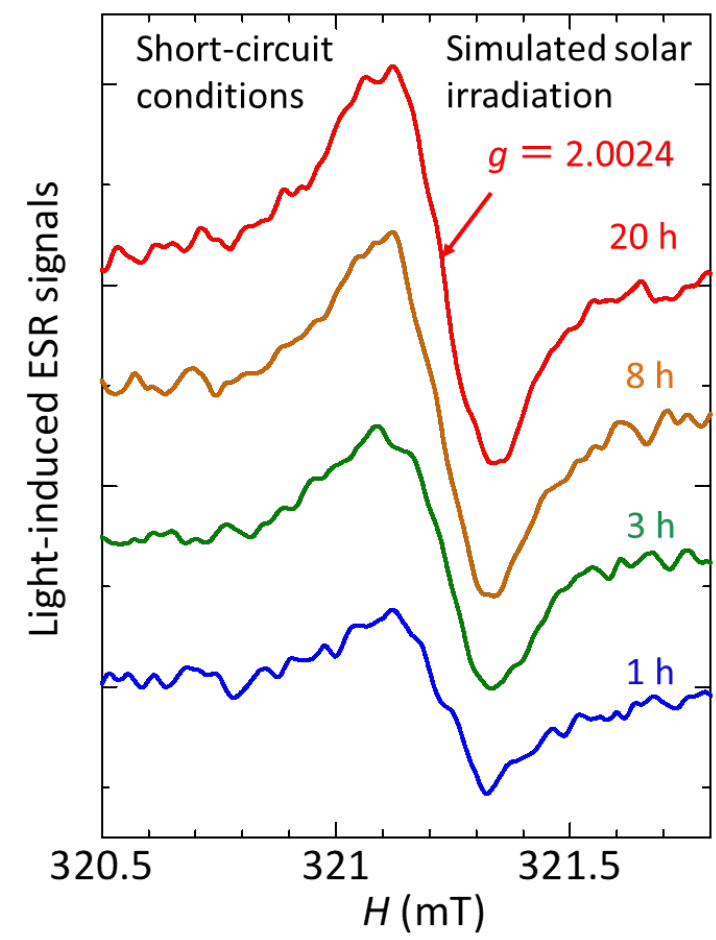

(b)

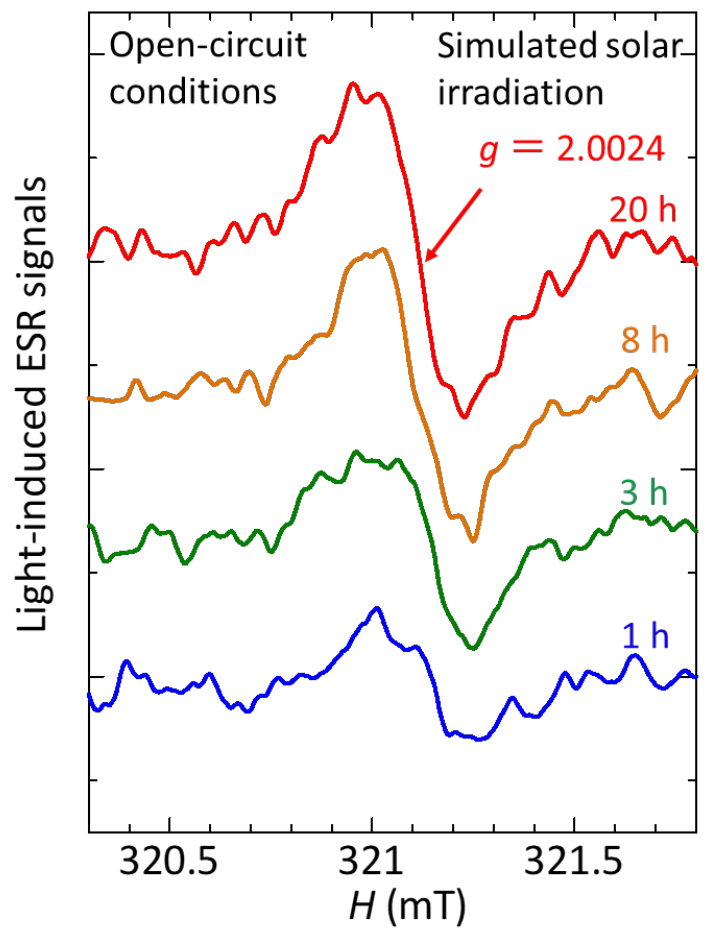

Figure 2. Time variation of light-induced ESR spectra for PTzNTz solar cells under simulated solar irradiation at RT under (a) short- and (b) open-circuit conditions. 
(a)

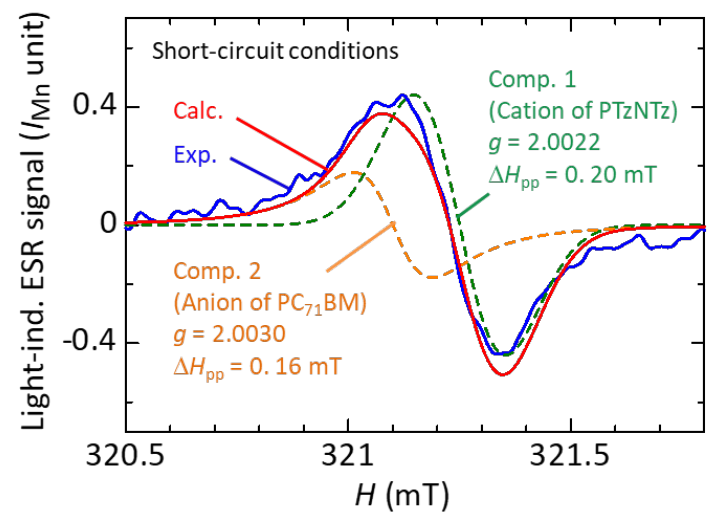

(b)

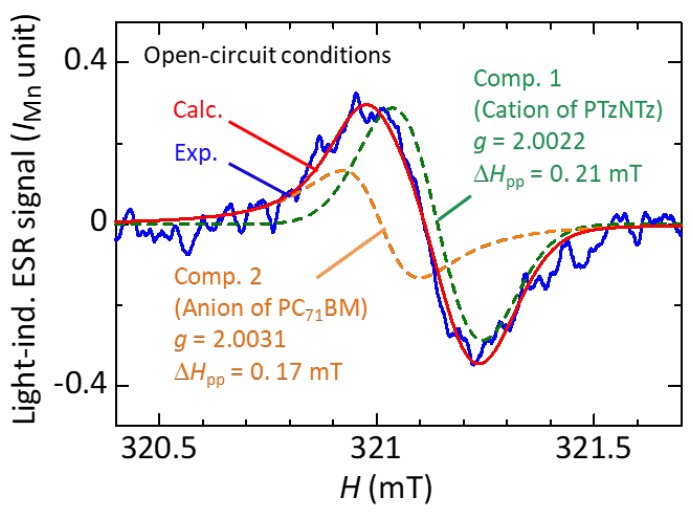

Figure 3. Fitting analyses for light-induced ESR spectra of the cells under (a) short- and (b) open-circuit conditions after $20 \mathrm{~h}$ simulated solar irradiation.

(a)

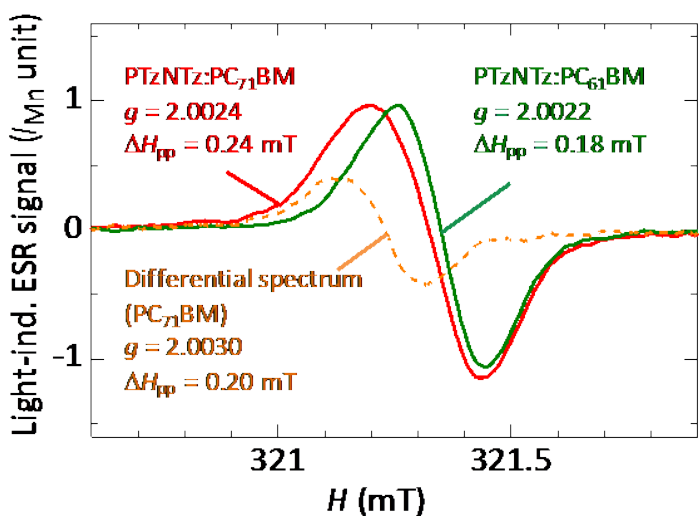

(b)

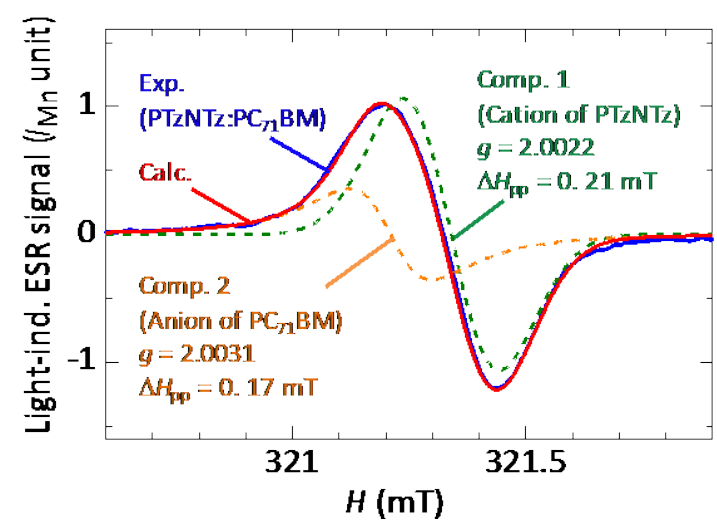

Figure 4. (a) Light-induced ESR spectra for PTzNTz:PC ${ }_{71} \mathrm{BM}$ (red line) and PTzNTz:PC ${ }_{61} \mathrm{BM}$ (green line) thin-film samples. Orange dotted line is the differential spectrum between the PTzNTz:PC 71 BM (red line) and PTzNTz:PC ${ }_{61} \mathrm{BM}$ (green line). (b) Fitting analysis for the lightinduced ESR spectrum of the PTzNTz:PC ${ }_{71} \mathrm{BM}$ thin-film sample (blue line) in (a). Red line is the sum of green dotted line (cation of PTzNTz) and orange dotted line (anion of $\mathrm{PC}_{71} \mathrm{BM}$ ). 
(a)

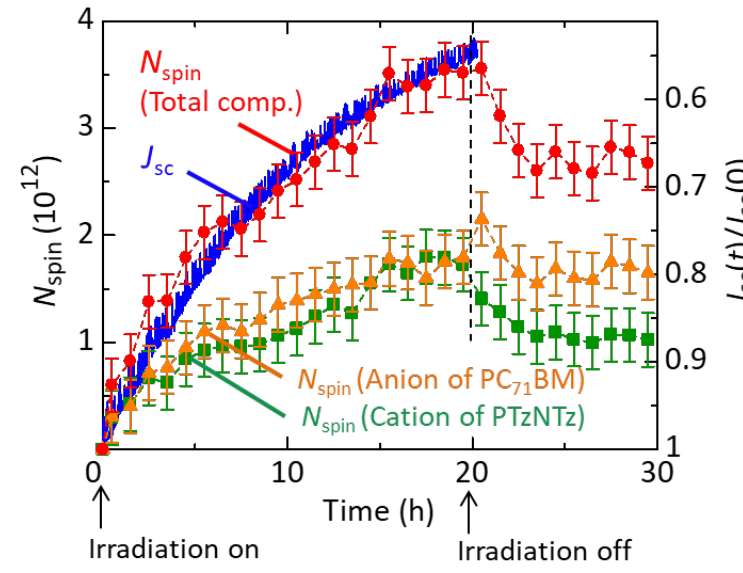

(b)

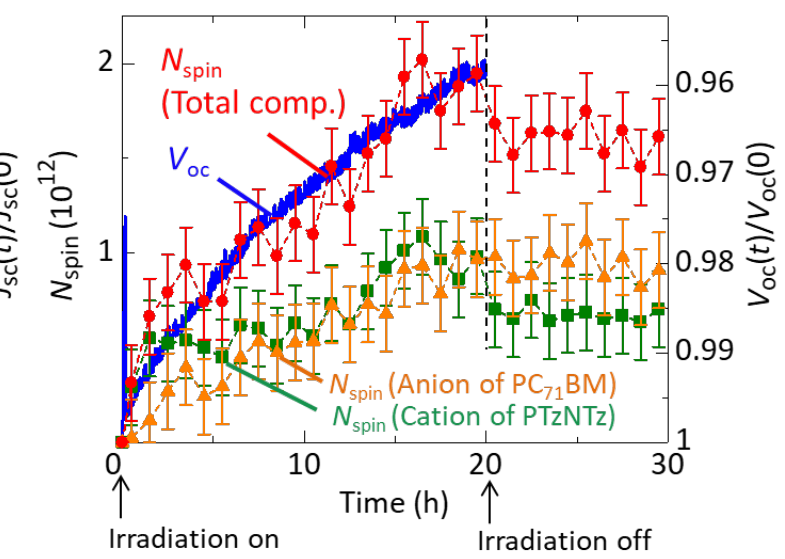

Figure 5. Transient responses of the $N_{\text {spin }}$ (red circles) and (a) relative short-circuit current density $\left(J_{\mathrm{sc}}(t) / J_{\mathrm{sc}}(0)\right)$ (blue line) or (b) relative open-circuit voltage $\left(V_{\mathrm{oc}}(t) / V_{\mathrm{oc}}(0)\right)$ (blue line) for the cells upon simulated solar irradiation at RT.

(a)

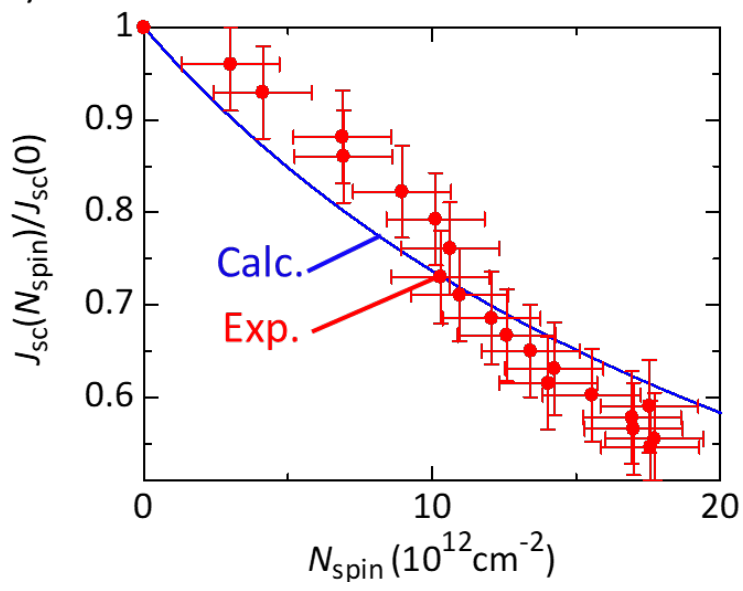

(b)

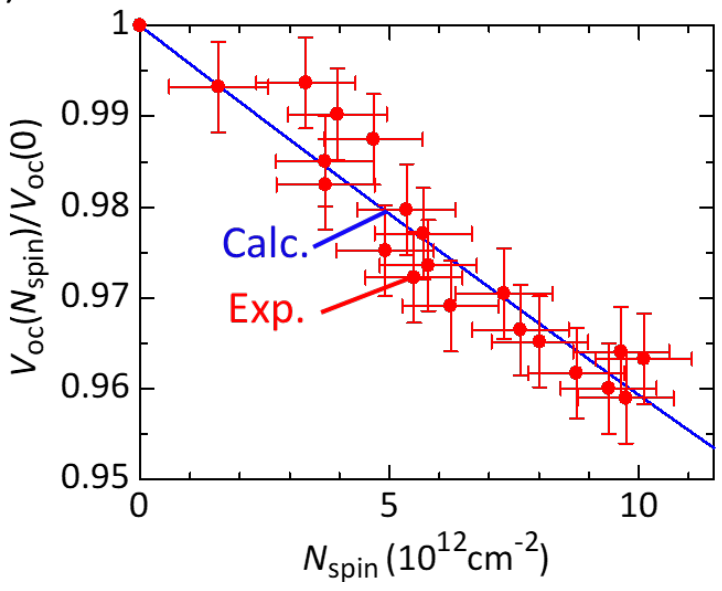

Figure 6. Dependence of (a) $J_{\mathrm{sc}}\left(N_{\mathrm{spin}}\right) / J_{\mathrm{sc}}(0)$ and (b) $V_{\mathrm{oc}}\left(N_{\mathrm{spin}}\right) / V_{\mathrm{oc}}(0)$ of the cell on the $N_{\text {spin. }}$.

Solid blue line shows the fitting results with (a) Equation (2) and (b) Equation (4), respectively. Red circles show the experimentally obtained data. 
(a)

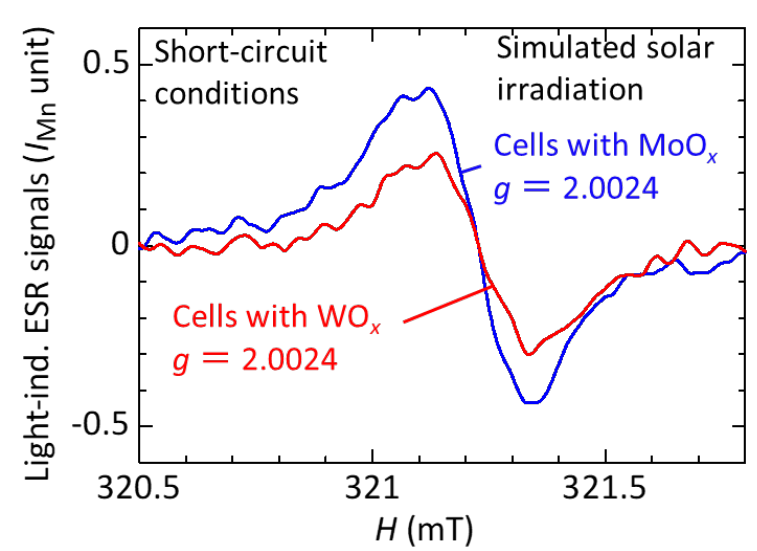

(b)

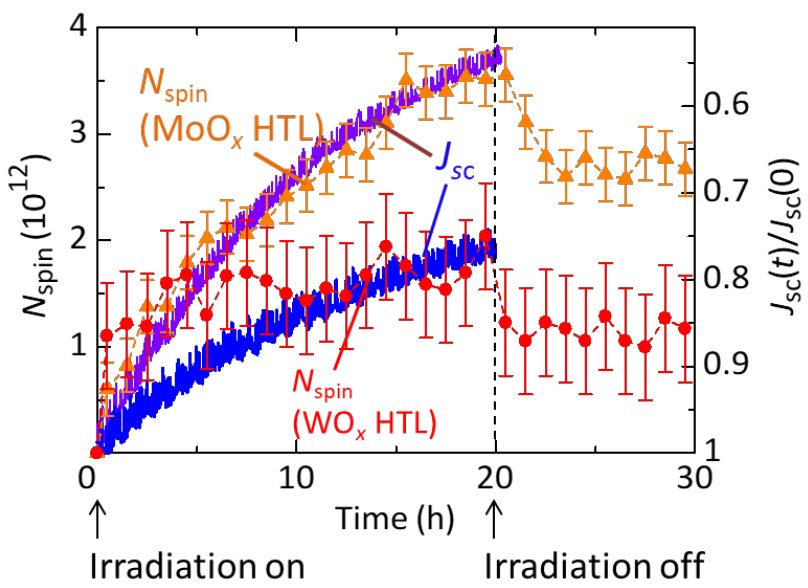

Figure 7. (a) Light-induced ESR spectra of cells with a $\mathrm{MoO}_{x} \mathrm{HTL}$ (blue line) or $\mathrm{WO}_{x} \mathrm{HTL}$ (red line). (b) Transient responses of the $N_{\text {spin }}$ for the cell with the $\mathrm{MoO}_{x} \mathrm{HTL}$ (orange triangles) and $J_{\mathrm{sc}}(t) / J_{\mathrm{sc}}(0)$ (purple line) and the $N_{\text {spin }}$ for the cell with the $\mathrm{WO}_{x} \mathrm{HTL}$ (red circles) and $J_{\mathrm{sc}}$ $(t) / J_{\text {sc }}(0)$ (blue line) upon simulated solar irradiation at RT. 
(a)

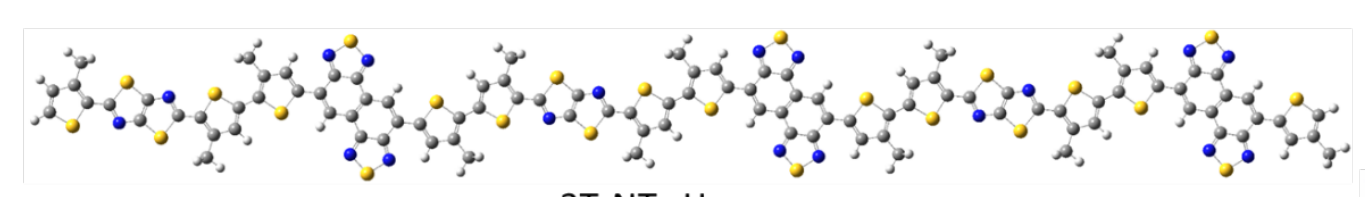

(b)

b) $3 T 2 N T z-H \quad$ N

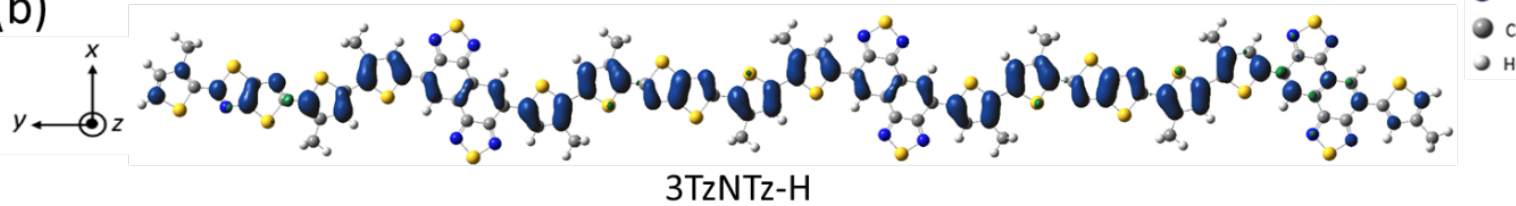

(c)

)

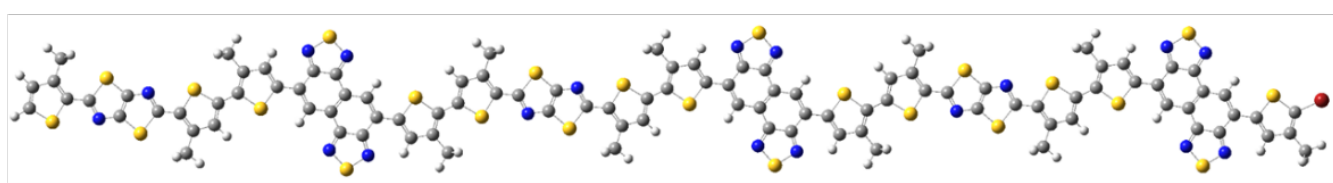

3TzNTz-Br

(d)

$\int^{2} \int^{2}$

Figure 8. (a,c) Model trimer molecules of PTzNTz for the DFT calculation: (a) 3TzNTz-H and (c) 3TzNTz-Br. (b,d) Distribution of spin density of the trimers for a cationic state: (b) 3TzNTz$\mathrm{H}$ and (d) $3 \mathrm{TzNTz}-\mathrm{Br}$ 
Table 1. Observed $g$ factors and $\Delta H_{\mathrm{pp}}$ of PTzNTz:PC71BM solar cells under short- or opencircuit conditions and PTzNTz:PC71BM thin-film.

\begin{tabular}{lll}
\hline \hline Sample & $g$ factor & $\Delta H_{\mathrm{pp}}(\mathrm{mT})$ \\
\hline Solar cell under short-circuit cond. & $2.0024 \pm 0.0002$ & $0.27 \pm 0.02$ \\
Solar cell under open-circuit cond. & $2.0024 \pm 0.0002$ & $0.26 \pm 0.02$ \\
PTzNTz:PC $71 \mathrm{BM}$ thin film & $2.0024 \pm 0.0001$ & $0.24 \pm 0.02$ \\
\hline \hline
\end{tabular}

Table 2. Fitting analyses for $g$ factors and $\Delta H_{\mathrm{pp}}$ of Comp. 1 and Comp. 2 of PTzNTz:PC $71 \mathrm{BM}$ solar cells under short- or open-circuit conditions and PTzNTz:PC $71 \mathrm{BM}$ thin film.

\begin{tabular}{lllll}
\hline \hline \multirow{2}{*}{ Sample } & \multicolumn{3}{l}{ Comp. 1 } & \multicolumn{3}{l}{ Comp. 2 } \\
\cline { 2 - 5 } & $g$ factor & $\Delta H_{\mathrm{pp}}(\mathrm{mT})$ & $g$ factor & $\Delta H_{\mathrm{pp}}(\mathrm{mT})$ \\
\hline $\begin{array}{l}\text { Solar cell under short-circuit } \\
\text { cond. }\end{array}$ & $2.0022 \pm 0.0002$ & $0.20 \pm 0.02$ & $2.0030 \pm 0.0002$ & $0.16 \pm 0.02$ \\
$\begin{array}{l}\text { Solar cell under open-circuit } \\
\text { cond. }\end{array}$ & $2.0022 \pm 0.0002$ & $0.21 \pm 0.02$ & $2.0031 \pm 0.0002$ & $0.17 \pm 0.02$ \\
PTzNTz:PC71BM thin film & $2.0022 \pm 0.0001$ & $0.21 \pm 0.02$ & $2.0031 \pm 0.0001$ & $0.17 \pm 0.02$ \\
\hline \hline
\end{tabular}


Table 3. Calculated $g$-tensors' principal values and their average $\left(g_{\text {ave }}\right)$ of model molecules of PTzNTz without bromine (TzNTz-H, 2TzNTz-H, and 3TzNTz-H) and PTzNTz with bromine (TzNTz-Br, 2TzNTz-Br, and 3TzNTz-Br).

\begin{tabular}{llllll}
\hline \hline $\begin{array}{l}\text { Model } \\
\text { molecules }\end{array}$ & Oligomer & $g_{x}$ & $g_{y}$ & $g_{z}$ & $g_{\text {ave }}$ \\
\hline TzNTz-H & Monomer & 2.00292 & 2.00124 & 2.00215 & 2.00210 \\
2TzNTz-H & Dimer & 2.00269 & 2.00109 & 2.00214 & 2.00197 \\
3TzNTz-H & Trimer & 2.00270 & 2.00119 & 2.00213 & 2.00201 \\
TzNTz-Br & Monomer & 2.00483 & 2.00312 & 2.00193 & 2.00329 \\
2 TzNTz-Br & Dimer & 2.00313 & 2.00170 & 2.00207 & 2.00230 \\
3 TzNTz-Br & Trimer & 2.00293 & 2.00152 & 2.00210 & 2.00218 \\
\hline \hline
\end{tabular}


ASSOCIATED CONTENT

Supporting Information

Light-induced ESR measurements at 50K, Density functional theory (DFT) calculation, Performance of PTzNTz polymer solar cells.

\section{AUTHOR INFORMATION}

\section{Corresponding Author}

*E-mail: marumoto@ims.tsukuba.ac.jp

\section{Notes}

The authors declare no competing financial interests.

\section{Acknowledgements}

This work has been partially supported by JSPS KAKENHI Grant Number JP15K13329, by

JST PRESTO, by The Hitachi Global Foundation, by The MIKIYA Science And Technology

Foundation, by The Futaba Foundation, and by JST ALCA Grant Number JPMJAL1603,

Japan. 


\section{REFERENCES}

(1) Günes, S.; Neugebauer, H.; Sariciftci, N. S. Conjugated Polymer-Based Organic Solar Cells. Chem. Rev. 2007, 107, 1324-1338.

(2) Clarke, T. M.; Durrant, J. R. Charge Photogeneration in Organic Solar Cells. Chem. Rev. 2010, 110, 6736-6767.

(3) Søndergaard, R.; Hösel, M.; Angmo, D.; Larsen-Olsen, T. T.; Krebs, F. C. Roll-to-Roll Fabrication of Polymer Solar Cells. Mater. Today 2012, 15, 36-49.

(4) Kim, K.; Liu, J.; Namboothiry, M. A. G.; Carroll, D. L. Roles of Donor and Acceptor Nanodomains in 6\% Efficient Thermally Annealed Polymer Photovoltaics. Appl. Phys. Lett. 2007, 90, 163511.

(5) Kim, J. Y.; Lee, K.; Coates, N. E.; Moses, D.; Nguyen, T. Q.; Dante, M.; Heeger, A. J. Efficient Tandem Polymer Solar Cells Fabricated by All-Solution Processing. Science $\mathbf{2 0 0 7}, 317,222-225$.

(6) Nagamori, T.; Marumoto, K. Direct Observation of Hole Accumulation in Polymer Solar Cells during Device Operation Using Light-Induced Electron Spin Resonance. $A d v$. Mater. 2013, 25, 2362-2367.

(7) Kubodera, T.; Yabusaki, M.; Rachmat, V. A. S. A.; Cho, Y.; Yamanari, T.; Yoshida, Y.;

Kobayashi, N.; Marumoto, K. Operando Direct Observation of Charge Accumulation 
and the Correlation with Performance Deterioration in PTB7 Polymer Solar Cells. ACS Appl. Mater. Interfaces 2018, 10, 26434-26442.

(8) Rachmat, V. A. S. A.; Kubodera, T.; Son, D.; Cho, Y.; Marumoto, K. Molecular Oriented Charge Accumulation in High-Efficiency Polymer Solar Cells as Revealed by Operando Spin Analysis. ACS Appl. Mater. Interfaces 2019, 11, 31129-31138.

(9) Saito, M.; Osaka, I.; Suzuki, Y.; Takimiya, K.; Okabe, T.; Ikeda, S.; Asano, T. Highly Efficient and Stable Solar Cells Based on Thiazolothiazole and Naphthobisthiadiazole Copolymers. Sci. Rep. 2015, 5, 14202.

(10) Seemann, A.; Sauermann, T.; Lungenschmied, C.; Armbruster, O.; Bauer, S.; Egelhaaf, H. J.; Hauch, J. Reversible and Irreversible Degradation of Organic Solar Cell Performance by Oxygen. Sol. Energy 2011, 85, 1238-1249.

(11) Jørgensen, M.; Norrman, K.; Gevorgyan, S. A.; Tromholt, T.; Andreasen, B.; Krebs, F. C. Stability of Polymer Solar Cells. Advanced Materials. 2012, pp 580-612.

(12) Soon, Y. W.; Cho, H.; Low, J.; Bronstein, H.; McCulloch, I.; Durrant, J. R. Correlating Triplet Yield, Singlet Oxygen Generation and Photochemical Stability in Polymer/Fullerene Blend Films. Chem. Commun. 2013, 49, 1291-1293.

(13) Chang, C. Y.; Chou, C. T.; Lee, Y. J.; Chen, M. J.; Tsai, F. Y. Thin-Film Encapsulation of Polymer-Based Bulk-Heterojunction Photovoltaic Cells by Atomic Layer Deposition. Org. Electron. 2009, 10, 1300-1306. 
(14) Sarkar, S.; Culp, J. H.; Whyland, J. T.; Garvan, M.; Misra, V. Encapsulation of Organic Solar Cells with Ultrathin Barrier Layers Deposited by Ozone-Based Atomic Layer Deposition. Org. Electron. 2010, 11, 1896-1900.

(15) Hermenau, M.; Schubert, S.; Klumbies, H.; Fahlteich, J.; Müller-Meskamp, L.; Leo, K.; Riede, M. The Effect of Barrier Performance on the Lifetime of Small-Molecule Organic Solar Cells. Sol. Energy Mater. Sol. Cells 2012, 97, 102-108.

(16) Lee, H. J.; Kim, H. P.; Kim, H. M.; Youn, J. H.; Nam, D. H.; Lee, Y. G.; Lee, J. G.; Mohd Yusoff, A. R. Bin; Jang, J. Solution Processed Encapsulation for Organic Photovoltaics. Sol. Energy Mater. Sol. Cells 2013, 111, 97-101.

(17) Clark, M. D.; Jespersen, M. L.; Patel, R. J.; Leever, B. J. Ultra-Thin Alumina Layer Encapsulation of Bulk Heterojunction Organic Photovoltaics for Enhanced Device Lifetime. Org. Electron. 2014, 15, 1-8.

(18) Abdel-Fattah, T. M.; Younes, E. M.; Namkoong, G.; El-Maghraby, E. M.; Elsayed, A. H.; Abo Elazm, A. H. Stability Study of Low and High Band Gap Polymer and Air Stability of PTB7:PC71BM Bulk Heterojunction Organic Photovoltaic Cells with Encapsulation Technique. Synth. Met. 2015, 209, 348-354.

(19) Singh, A.; Dey, A.; Das, D.; Iyer, P. K. Effect of Dual Cathode Buffer Layer on the Charge Carrier Dynamics of RrP3HT:PCBM Based Bulk Heterojunction Solar Cell. ACS Appl. Mater. Interfaces 2016, 8, 10904-10910. 
(20) Marumoto, K.; Kuroda, S. I.; Takenobu, T.; Iwasa, Y. Spatial Extent of Wave Functions of Gate-Induced Hole Carriers in Pentacene Field-Effect Devices as Investigated by Electron Spin Resonance. Phys. Rev. Lett. 2006, 97, 256603.

(21) Marumoto, K.; Arai, N.; Goto, H.; Kijima, M.; Murakami, K.; Tominari, Y.; Takeya, J.; Shimoi, Y.; Tanaka, H.; Kuroda, S.; et al. Microscopic Mechanisms behind the High Mobility in Rubrene Single-Crystal Transistors as Revealed by Field-Induced Electron Spin Resonance. Phys. Rev. B 2011, 83, 075302.

(22) Son, D.; Kuwabara, T.; Takahashi, K.; Marumoto, K. Direct Observation of UV-Induced Charge Accumulation in Inverted-Type Polymer Solar Cells with a TiOxlayer: Microscopic Elucidation of the Light-Soaking Phenomenon. Appl. Phys. Lett. 2016, 109, 133301.

(23) Sato, G.; Son, D.; Ito, T.; Osawa, F.; Cho, Y.; Marumoto, K. Direct Observation of Radical States and the Correlation with Performance Degradation in Organic LightEmitting Diodes During Device Operation. Phys. Status Solidi A 2018, 215, 1700731.

(24) Kraffert, F.; Steyrleuthner, R.; Albrecht, S.; Neher, D.; Scharber, M. C.; Bittl, R.; Behrends, J. Charge Separation in PCPDTBT:PCBM Blends from an EPR Perspective. J. Phys. Chem. C 2014, 118, 28482-28493. 
(25) Biskup, T.; Sommer, M.; Rein, S.; Meyer, D. L.; Kohlstädt, M.; Würfel, U.; Weber, S. Ordering of PCDTBT Revealed by Time-Resolved Electron Paramagnetic Resonance Spectroscopy of Its Triplet Excitons. Angew. Chem. Int. Ed., 2015, 54, 7707-7710.

(26) Krinichnyi, V.I.; Yudanova, E.I. Influence of Morphology of Low-Band-Gap PCDTBT:PC $71 B M$ Composite on Photoinduced Charge Transfer: LEPR Spectroscopy Study. Synth. Met. 2015, 210, 148-155.

(27) Tayebjee1, M. J. Y.; Sanders, S. N.; Kumarasamy, E.; Campos, L. M.; Sfeir, M. Y.; McCamey, D. R. Quintet Multiexciton Dynamics in Singlet Fission. Nat. Phys. 2017, 13, 182-189.

(28) Salvadori, E.; Luke, N.; Shaikh, J.; Leventis, A.; Bronstein, H.; Kay, C. W. M.; Clarke, T. M. Ultra-Fast Spin-Mixing in a Diketopyrrolopyrrole Monomer/Fullerene Blend Charge Transfer State. J. Mater. Chem. A 2017, 5, 24335-24343.

(29) Kobori, Y.; Ako, T.; Oyama, S.; Tachikawa, T.; Marumoto, K. Transient Electron Spin Polarization Imaging of Heterogeneous Charge-Separation Geometries at BulkHeterojunction Interfaces in Organic Solar Cells. J. Phys. Chem. C 2019, 123, 1347213481. 
(30) Sperlich, A.; Liedtke, M.; Kern, J.; Kraus, H.; Deibel, C.; Filippone, S.; Delgado, Juan L.; Martín, N.; Dyakonov, V. Photoinduced C70 Radical Anions in Polymer: Fullerene Blends. Phys. Status Solidi RRL 2011, 5, 128-130

(31) Niklas, J.; Mardis, K. L.; Banks, B. P.; Grooms, G. M.; Sperlich, A.; Dyakonov, V.; Beaupré, S.; Leclerc, M.; Xu, T.; Yu, L.; et al. Highly-Efficient Charge Separation and Polaron Delocalization in Polymer-Fullerene Bulk-Heterojunctions: A Comparative Multi-Frequency EPR and DFT Study. Phys. Chem. Chem. Phys. 2013, 15, 9562-9574.

(32) Lukina, E. A.; Uvarov, M. N.; Kulik, L. V. Charge Recombination in P3HT/PC $70 B M$ Composite Studied by Light-Induced EPR. J. Phys. Chem. C 2014, 118, 18307-18314.

(33) Dyakonov, V.; Zoriniants, G.; Scharber, M.; Brabec, C. J. Photoinduced Charge Carriers in Conjugated Polymer - Fullerene Composites Studied with Light-Induced ElectronSpin Resonance. 1999, 59, 8019-8025.

(34) Marumoto, K.; Takeuchi, N.; Ozaki, T.; Kuroda, S. ESR Studies of Photogenerated Polarons in Regioregular Poly(3-Alkylthiophene)-Fullerene Composite. Synth. Met. 2002, 129, 239-247.

(35) Marumoto, K.; Kato, M.; Kondo, H.; Kuroda, S. Electron Spin Resonance and Electron Nuclear Double Resonance of Photogenerated Polarons in Polyfluorene and Its Fullerene Composite. 2009, 79, 245204. 
(36) Marumoto, K.; Nagamori, T. Correlation between Hole Accumulation and Deterioration of Device Performance in Polymer Solar Cells as Investigated by Light-Induced Electron Spin Resonance. Mol. Cryst. Liq. Cryst. 2014, 597, 29-32.

(37) Liu, D.; Nagamori, T.; Yabusaki, M.; Yasuda, T.; Han, L.; Marumoto, K. Dramatic Enhancement of Fullerene Anion Formation in Polymer Solar Cells by Thermal Annealing: Direct Observation by Electron Spin Resonance. Appl. Phys. Lett. 2014, 104, 243903.

(38) Orimo, A.; Masuda, K.; Honda, S.; Benten, H.; Ito, S.; Ohkita, H.; Tsuji, H. Surface Segregation at the Aluminum Interface of Poly(3-Hexylthiophene)/Fullerene Solar Cells. Appl. Phys. Lett. 2010, 96, 043305.

(39) Yin, Z.; Wei, J.; Zheng, Q. Interfacial Materials for Organic Solar Cells: Recent Advances and Perspectives. Adv. Sci. 2016, 3, 1500362.

(40) Frisch, M. J.; Trucks, G. W.; Schlegel, H. B.; Scuseria, G. E.; Robb, M. A.; Cheeseman, J. R.; Scalmani, G.; Barone, V.; Mennucci, B.; Petersson, G. A.; Nakatsuji, H.; Caricato, M.; Li, X.; Hratchian, H. P.; Izmaylov, A. F.; Bloino, J.; Zheng, G.; Sonnenberg, J. L.; Hada, M.; Ehara, M.; Toyota, K.; Fukuda, R.; Hasegawa, J.; Ishida, M.; Nakajima, T.; Honda, Y.; Kitao, O.; Nakai, H.; Vreven, T.; Montgomery, J. A., Jr.; Peralta, J. E.; Ogliaro, F.; Bearpark, M.; Heyd, J. J.; Brothers, E.; Kudin, K. N.; Staroverov, V. N.; Kobayashi, R.; Normand, J.; Raghavachari, K.; Rendell, A.; Burant, J. C.; Iyengar, S. S.; 
Tomasi, J.; Cossi, M.; Rega, N.; Millam, J. M.; Klene, M.; Knox, J. E.; Cross, J. B.;

Bakken, V.; Adamo, C.; Jaramillo, J.; Gomperts, R.; Stratmann, R. E.; Yazyev, O.;

Austin, A. J.; Cammi, R.; Pomelli, C.; Ochterski, J. W.; Martin, R. L.; Morokuma, K.;

Zakrzewski, V. G.; Voth, G. A.; Salvador, P.; Dannenberg, J. J.; Dapprich, S.; Daniels,

A. D.; Farkas, O”.; Foresman, J. B.; Ortiz, J. V.; Cioslowski, J.; Fox, D. J. Gaussian 09, revision D.01, Gaussian, Inc., Wallingford, CT, 2013.

(41) McCullough, R. D.; Williams, S. P.; Lowe, R. D.; Jayaraman, M.; Tristram-Nagle, S.

Self-Orienting Head-to-Tail Poly(3-Alkylthiophenes): New Insights on StructureProperty Relationships in Conducting Polymers. J. Am. Chem. Soc. 1993, 115, 49104911.

(42) Chen, T. A.; Wu, X.; Rieke, R. D. Regiocontrolled Synthesis of Poly(3-Alkylthiophenes) Mediated by Rieke Zinc: Their Characterization and Solid-State Properties. J. Am. Chem. Soc. 1995, 117, 233-244.

(43) Loewe, R. S.; Khersonsky, S. M.; McCullough, R. D. A Simple Method to Prepare Headto-Tail Coupled, Regioregular Poly(3-Alkylthiophenes) Using Grignard Metathesis. $A d v$. Mater. 1999, 11, 250-253.

(44) Tamai, Y.; Ohkita, H.; Namatame, M.; Marumoto, K.; Shimomura, S.; Yamanari, T.; Ito, S. Light-Induced Degradation Mechanism in Poly(3-Hexylthiophene)/Fullerene Blend Solar Cells. Adv. Energy Mater. 2016, 6, 1600171. 
Table of Contents (TOC) graphic

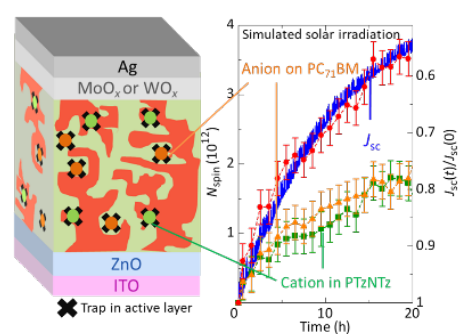

